\title{
GROWTH PERFORMANCES OF BROILERS HYBRO G+ PROVENIENCE
}

\section{S. Lilić ${ }^{1}$, D. Šefer ${ }^{2}$, S. Dimitrijević ${ }^{2}$, T. Ilić ${ }^{2}$, S. Ivanović ${ }^{3}$, V. Matekalo- Sverak $^{1}$}

\footnotetext{
${ }^{1}$ Institut of Meat Hygiene and Technology, Kaćanskog 13, 11000 Belgrade, Republic of Serbia

${ }^{2}$ Faculty of Veterinary Medicine, Bulevar oslobođenja 18, 11000 Belgrade, Republic of Serbia

${ }^{3}$ Scientific Veterinary Institute of Serbia, Autoput 3, 11070 Belgrade, Republic of Serbia

Corresponding author: slobo@inmesbgd.com

Original scientific paper
}

Abstract: In this paper are presented the growth performances (live weight, average daily weight gain, feed consumption and feed conversion ratio) of broilers Hybro $\mathrm{G}+$ provenience. Feeding, zoohygienic and zootechnical measures met technological normative for this provenience. Broilers were fed with the complete feed mixtures (producer „Dren“, Novi Sad) with added anticoccidial salinomycine in the amount of $66 \mathrm{mg} / \mathrm{kg}$ up to 35. day of fattening. In last week of the fattening period, salinomycine was not added (drug waiting period is 5 days). Live weight of broilers at the end of trial was $1959.74 \mathrm{~g}$ to $2750.48 \mathrm{~g}$ (average $2340.62 \mathrm{~g}$ ). During the fattening period, average daily weight gain was $54.70 \pm$ $5.03 \mathrm{~g}$; it was in the range 45.71-64.39 g. Average daily feed consumption was $87.97 \mathrm{~g}$ for all fattening period and feed conversion ratio was $87.97 \mathrm{~g}$.

Key words: broilers, Hybro G+ provenience, growth performances

\section{Introduction}

Chicken meat production presents $80 \%$ of total poultry meat production and has the largest increase relating to meat of other animal species. Broiler fattening period lasts short and feed conversion ratio is low. Chicken meat consumption constantly increase due to low price, attractive sensory properties and there are no cultural and religious opposites of consumption.

The goal of intensive broilers fattening is to achieve as much better growth performances as possible with fewer costs that can be observed in low daily feed consumption, low feed conversion ratio and larger daily weight gain.

Growth performances depend on genetic background (provenience), kind and quality of feed mixtures, feeding, ambient conditions and compliance of zoohygienic and zootechnical conditions of objects for animal breeding and, of course, of appearance of infective and parasitic diseases. 
Genetic factor directly impact on growth performances of broiler as well as on carcass conformation (Pavlovski et al., 2006) and chemical composition of meat (Ristic et al., 2007). One of the most important factors that impacts on growth performances of broilers is feed mixtures quality and use of some feedstuffs (Milošević et al., 2006). Nowadays, there are investigations about some additives in feed mixtures for improving of performances and decreasing of some infections and intoxications. Ivanović et al. (2009) investigated adding of probiotics in feed mixtures, Cabuk et al. (2004) and Radović et al. (2009) adding of mineral adsorbers and Marković et al. (2009) adding of microelements and vitamins to feed mixtures. Growth performances also depend on, of course, of appearance of infective and parasitic diseases in broilers (Lilić, 2007).

The aim of this paper was to investigate the growth performances of broilers Hybro $\mathrm{G}+$ provenience during 42 days of fattening.

\section{Materials and Methods}

In this experiment one-day broiler Hybro $\mathrm{G}^{+}$provenience was used. Farming, rearing, feeding and watering of broilers as well as use of prophylactic measures was adapted to floor raising. Before the experiment started the area for the trial was prepared. After mechanical cleaning and sanitation, equipment and floor were disinfected by biodegradable means with a wide specter of action. Litter was of wheat straw and semi-automatic drinkers, and feeders were situated. Feeding and watering were ad libitum. Zoohygienic and microclimatic conditions met technological normative for Hybro $\mathrm{G}+$ provenience (Technical information on Hybro G+ broilers).

Table 1. Feed mixtures composition, \%

\begin{tabular}{|l|c|c|c|c|}
\hline \multicolumn{1}{|c|}{ Index } & Pre-starter & Starter & Grower & Finisher \\
\hline Days & $1-7$ & $7-14$ & $14-35$ & $35-42$ \\
\hline Maize & 54.45 & 50.79 & 53.84 & 54.20 \\
\hline Wheat meal & 2.00 & 2.50 & 1.00 & 4.00 \\
\hline Soy-bean meal & 25.00 & 25.00 & 23.50 & 23.00 \\
\hline Sunflower meal & 5.00 & 5.00 & 6.00 & 5.00 \\
\hline Yeast & 3.00 & 3.00 & 3.00 & 3.00 \\
\hline Fish meal & 5.00 & 4.00 & 3.00 & - \\
\hline Dehydrated alfalfa meal & - & 2.00 & 2.00 & 2.00 \\
\hline Soy-bean oil & 3.00 & 5.00 & 4.50 & 5.50 \\
\hline Dicalcium phosphate & 1.00 & 1.20 & 1.30 & 1.10 \\
\hline Limestone & - & - & 0.20 & 0.40 \\
\hline Salt & 0.20 & 0.20 & 0.30 & 0.30 \\
\hline Lysine & 0.10 & 0.06 & 0.11 & 0.25 \\
\hline Methionine & 0.25 & 0.25 & 0.25 & 0.25 \\
\hline Premix & 1.00 & 1.00 & 1.00 & 1.00 \\
\hline
\end{tabular}


Broilers were fed with the complete feed mixtures (producer „Dren“, Novi $\mathrm{Sad}$ ) with added anticoccidial salinomycine in the amount of $66 \mathrm{mg} / \mathrm{kg}$ to 35 th day of fattening. In finisher, salinomycine was not added, because of the drug waiting period of 5 days. Feed mixture composition is presented in table 1 .

Chemical composition of feed mixtures, used for broilers feeding, met broilers nutrient needs and they were in accordance with technological normative for Hybro $\mathrm{G}^{+}$provenience. Chemical composition of feed mixtures is presented in table 2 .

Table 2. Chemical composition of feed mixtures, $\%$

\begin{tabular}{|l|c|c|c|c|}
\hline \multicolumn{1}{|c|}{ Index } & Pre-starter & Starter & Grower & Finisher \\
\hline Days & $1-7$ & $7-14$ & $14-35$ & $35-42$ \\
\hline Moisture & 11.03 & 10.72 & 10.79 & 20.85 \\
\hline Ash & 5.61 & 5.79 & 5.96 & 5.44 \\
\hline Crude protein & 22.73 & 22.23 & 21.34 & 19.48 \\
\hline Crude fat & 5.93 & 7.76 & 7.28 & 8.16 \\
\hline Crude cellulose & 3.94 & 4.37 & 4.51 & 4.37 \\
\hline Non-nitrogen extract & 50.76 & 49.12 & 50.12 & 51.69 \\
\hline Ca & 0.95 & 0.97 & 0.99 & 0.81 \\
\hline $\mathrm{P}$ & 0.86 & 0.85 & 0.85 & 0.71 \\
\hline ME, MJ/kg & 12.92 & 13.23 & 13.12 & 13.43 \\
\hline Lysine & 1.36 & 1.30 & 1.26 & 1.20 \\
\hline Methionine + cystine & 0.97 & 0.95 & 0.92 & 0.84 \\
\hline Triptophane & 0.31 & 0.31 & 0.29 & 0.27 \\
\hline
\end{tabular}

Health of broilers was observed daily by clinical examination. During the experiment, the growth performances obtained were: live weight, daily weight gain, daily feed consumption and feed conversion ratio.

Live weight was measured on the scale with accuracy of $10^{-3} \mathrm{~kg}$. Based on obtained data, average live weight and total weight gain were calculated.

During the experiment, the amount of feed mixtures was measured and according to sum of daily amounts of used feed, daily feed consumption and feed conversion ratio for each phase and for total fattening period were calculated.

Obtained results were analyzed statistically by calculating of average values, standard deviation, standard error, variation coefficient and range (Hadživuković, 1991).

\section{Results and Discussion}

Live weight of broilers is presented in Table 3. Average live weight of oneday broilers was $43.12 \pm 2.42 \mathrm{~g}$ (39.25-46.82 g). After 42 days (end of trial), live 
weight of broilers was in the range of 1959.74-2750.48 $\mathrm{g}$ and average live weight was $2340.62 \mathrm{~g}$. There was no mortality during the fattening. In accordance with the variation coefficient, which was not above $30 \%$, live weight of broilers was statistically similar during each fattening period.

Table 3. Live weight of broilers during fattening, $\mathrm{g}, \mathrm{n}=\mathbf{2 5}$

\begin{tabular}{|c|c|c|c|c|c|}
\hline Days & $\overline{\mathrm{X}}$ & $\mathrm{Sx}$ & $\mathrm{Sd}$ & $\mathrm{Cv}$ & Range \\
\hline 1 & 43.12 & 0.48 & 2.42 & 5.60 & $39.25-46.82$ \\
\hline 21 & 666.27 & 19.30 & 96.49 & 14.48 & $480.85-852.41$ \\
\hline 28 & 1189.95 & 37.11 & 177.99 & 14.96 & $912.17-1503.65$ \\
\hline 35 & 1808.32 & 45.44 & 192.78 & 10.66 & $1543.76-2214.25$ \\
\hline 42 & 2340.62 & 50.02 & 212.22 & 9.07 & $1959.74-2750.48$ \\
\hline
\end{tabular}

The average daily gain of broilers (Table 4) was $30.02 \pm 4.21 \mathrm{~g}$ after 21 days of fattening. During the fattening, average daily gain was constantly increasing and on 28th day was $72.62 \pm 14.65 \mathrm{~g}$, on 35th day was $78.98 \pm 10.45 \mathrm{~g}$ and on 42 nd day was $76.04 \pm 5.42 \mathrm{~g}$. For the whole fattening period, average daily gain was $54.70 \pm 5.03 \mathrm{~g}$, ranged $45.71-64.39 \mathrm{~g}$.

Table 4. Daily weight gain during the fattening, $\mathrm{g}, \mathrm{n}=\mathbf{2 5}$

\begin{tabular}{|c|c|c|c|c|c|}
\hline Days & $\overline{\mathrm{X}}$ & $\mathrm{Sx}$ & $\mathrm{Sd}$ & $\mathrm{Cv}$ & Iv \\
\hline 21 & 30.02 & 0.84 & 4.21 & 14.03 & $21.04-38.39$ \\
\hline 28 & 72.62 & 4.79 & 14.65 & 20.17 & $52.14-96.14$ \\
\hline 35 & 78.98 & 7.23 & 10.45 & 13.24 & $69.21-101.51$ \\
\hline 42 & 76.04 & 6.81 & 5.42 & 7.12 & $59.36-85.29$ \\
\hline $1-42$ & 54.70 & 4.93 & 5.03 & 9.19 & $45.71-64.39$ \\
\hline
\end{tabular}

Average daily feed consumption (Table 5) was increased during the each period of measuring and it was $43.19 \mathrm{~g}$ (1-21st day), $109.44 \mathrm{~g}$ (21-28th day), $150.06 \mathrm{~g}$ (28-35th day), $164.14 \mathrm{~g}$ (35-42nd day) and $87.97 \mathrm{~g}$ (for the whole period of fattening). Feed conversion ratio was also increased during the fattening, from 1.46 that was from 1-21st day of fattening up to 2.16 that was calculated from 3542nd day of fattening. For whole fattening it was 1.76. In this experiment it was obtained significantly larger values for feed conversion ratio according to technological normative for Hybro $\mathrm{G}+$ provenience. In this document it is stated that feed conversion ratio is in the first week 0.90 , in the second 0.98 , in the third 1.17, in the fourth 1.37, in the fifth 1.52 and in finishing week 1.64 (Technical information on Hybro G+ broilers). 
Tabela 5 Average daily feed consumption (g) and feed conversion ratio during the fattening

\begin{tabular}{|l|c|c|c|c|c|}
\hline Indicator / Days & $1-21$ & $21-28$ & $28-35$ & $35-42$ & $1-42$ \\
\hline Average daily feed consumption & 43,19 & 109,44 & 150,06 & 164,14 & 87,97 \\
\hline Feed conversion ratio & 1,46 & 1,51 & 1,90 & 2,16 & 1,76 \\
\hline
\end{tabular}

Live weight of broilers during and at the end of fattening is one of the main parameters that is used for assessment of growth performances and it depends on many factors such as: feed mixture quality, average daily feed consumption, feed conversion ratio and compliance of optimal zootechnical conditions on the farm and appearance of infective and non-infective diseases. Growth performances are used for estimation of success of fattening and they are one of the main parameters that impact carcass yield and broiler meat quality.

\title{
Conclusion
}

During the fattening, health status of broilers was well without clinical symptoms of infective and parasitic diseases.

After 42 days of fattening broilers achieved average live weight of 2340.62 $\mathrm{g}(1959.74-2750.48 \mathrm{~g})$.

For whole fattening period, average daily gain was $54.70 \pm 5.03 \mathrm{~g}$, ranged 45.71-64.39 g.

Average daily feed consumption was increased during the each period of measuring and it was $43.19 \mathrm{~g}$ (1-21st day), $109.44 \mathrm{~g}$ (21-28th day), $150.06 \mathrm{~g}$ (2835th day), $164.14 \mathrm{~g}$ (35-42nd day) and $87.97 \mathrm{~g}$ (for the whole period of fattening).

Feed conversion ratio was also increased during the fattening, from 1.46 (from 1-21st day of fattening) up to 2.16 (from 35-42nd day of fattening). For whole fattening feed conversion ratio was 1.76 .

\section{Proizvodni rezultati u tovu brojlera Hybro G+ provenijencije}

\author{
S. Lilić, D. Šefer, S. Dimitrijević, T. Ilić, S. Ivanović, V. Matekalo-Sverak
}

\section{Rezime}

U radu su prikazani proizvodni rezultati (masa brojlera tokom tova, prosečan dnevni prirast i utrošak hrane, konverzija hrane) brojlera Hybro G+ provenijencije. Ishrana, smeštaj, zoohigijenske i zootehničke mere odgovarale su tehnološkim normativima za ovu provenijenciju. Brojleri su hranjeni potpunim krmnim smešama (proizvođač „Dren“, Novi Sad) kojima je dodat antikokcidijal salinomicin u količini od $66 \mathrm{mg} / \mathrm{kg}$, do 35 . dana tova. U smeše korišćene za 
poslednju nedelju tova, salinomicin nije dodat da bi se ispoštovala karenca leka koja za pileće meso iznosi 5 dana. Prosečna masa brojlera na kraju tova bila je od $1959,74 \mathrm{~g}$ do $2750,48 \mathrm{~g}$ (prosečno 2340,62 g). Za ceo period tova, prosečan dnevni prirast brojlera bio je 54,70 $\pm 5,03 \mathrm{~g}$, odnosno bio je u opsegu od 45,71 do 64,39 g. Prosečan dnevni utrošak hrane bio je $87,97 \mathrm{~g}$ za ceo period tova, a konverzija hrane 1,76 .

\section{References}

CABUK M., ALCICEK A., BOZKURT M., AKKAN S. (2004): Effect of yucca schidigera and natural zeolite on broiler performance. International Journal of Poultry Science, 3, 10, 651-654.

HADŽIVUKOVIĆ S. (1991): Statistički metodi s primenom u poljoprivrednim i biološkim istraživanjima, drugo prošireno izdanje, Poljoprivredni fakultet, Institut za ekonomiku poljoprivrede i sociologiju sela, Novi Sad;

IVANOVIĆ S., BALTIĆ Ž.M., TEODOROVIĆ V., LILIĆ S., VELEBIT B. (2009): Einfluss von Probiotika auf die Mastleistungen von Broilern. Fleischwirtschaft, 7, 89, 100-102.

LILIĆ S. (2007): Ispitivanje uticaja infekcije brojlera protozoom Eimeria tenella na proizvodne rezultate pilića u tovu i neke parametre kvaliteta mesa. Doktorska disertacija. Fakultet veterinarske medicine, Univerzitet u Beogradu.

MARKOVIĆ R., BALTIĆ Ž.M., PETRUJKIĆ B., ŠEFER D., TODOROVIĆ E. (2009). Uticaj selena i vitamina E na kvalitet i prinos trupova brojlera. Tehnologija mesa, 50, 3-4, 195-200.

MILOŠEVIĆ N., STANAĆEV V., KOVČIN S. (2006): Kukuruzno stočno brašno $\mathrm{u}$ ishrani pilića u tovu. Biotechnolgy in animal husbandry, 22, 5-6, 71-79.

PAVLOVSKI Z., LUKIĆ M., CMILJANIĆ R., ŠKRBIĆ Z. (2006): Konformacija trupova pilića. Biotechnology in Animal Husbandry, 22, 3-4, 83-96.

RADOVIĆ V., KAROVIĆ D., OKANOVIĆ Đ., FILIPOVIĆ S., KORMANJOŠ Š. (2009): Uticaj mineralnih adsorbenata, dodatih u hranu, na neke proizvodne rezultate brojlera. Tehnologija mesa, 50, 5-6, 271-275.

RISTIĆ M., FREUDENREICH P., WERNER R., SCHÜSSLER G., KÖSTNER U, EHRHARDT S. (2007): Hemijski sastav mesa brojlera u zavisnosti od porekla i godine proizvodnje, Tehnologija mesa, 48, 3-6, 203-207.

TECHNICAL INFORMATION ON HYBRO G+ BROILERS, www.hybro.com. 